\title{
Study on the Ecology of Environmental Art Design
}

\author{
Ge Song \\ Wuchang Institute of Technology, Wuhan, Hubei, 430065
}

Keywords: Ecology Cycle, Environmental Art Design, Ecological Base

\begin{abstract}
Eco-Environmental Art Design As a new specialty of science and art for how to arrange objects and spaces on land and land to create a safe, efficient, healthy and comfortable environment for people, while providing comfort, fitness and aesthetics, The goal is no longer a single architectural environment, but a comprehensive cultural and ecological environment system. In view of the existing problems and contradictions in the process of environmental development and environmental ecology, the environment designers need to establish the concept of environmental ecology in the thought. In the environment design of the system, cultivate the aesthetic experience with the ecological environment, Do aesthetics and ecology complement each other. Contemporary and future environmental art design is an eco-sustainable environmental art design, advocating people to use the ecological aesthetic consciousness to use science and technology, to create the natural beauty, spiritual beauty and technical beauty as an environment, so as to promote human and environmental sustainability Development play an active guiding role.
\end{abstract}

\section{Introduction}

With the development of the times, the duality of industrialization and the physical and mental damage of mankind is becoming more and more serious. The sustainable development of human development and resources and environment is becoming more and more important. The "ecology" of environmental design is mainly from the human ecological requirements, Use natural and artificial materials such as sunlight, climate, flora and fauna, soil, water, etc. to study how to create a comfortable and good physical environment, while reducing the deprivation of resources, maintaining nutrition and water circulation, and maintaining plant growth, in accordance with the principles of natural biology Environmental and animal habitat quality to help improve the living environment and the health of the ecosystem. Environmental art designers in the design process in general to protect the environment and a good layout of the ecological pattern of the main, the environmental art design as an ecosystem maintenance process to treat. So that its design can not only adapt to the original structure of the surface, but also to minimize the human side effects, but also to ensure the integrity of the entire environmental structure. But also requires designers to minimize the ecological process of human interference and to ensure that the environment of animals, plants, water and other elements of the normal flow. In the green design, in order to make the design of the environment more reasonable and more ecologically, in the planning of planting green crops, the final selection of local crops often have to consider the choice of foreign crops, in order to better achieve the harmonious development of man and nature The

\section{The basis of environmental art design ecology}

Environmental art design can be understood as the way of art and means of building the internal and external environment planning, design activities. Its purpose is to provide a reasonable, reasonable, comfortable, beautiful and effective space for people's lives, work and social activities. It is a variety of scientific synthesis, in the actual creative design, in the development of other aspects of science and technology at the same time, pay close attention to ecological issues, the formation of ecological environment to protect the ecological sustainability of the design concept. Because the human material and spiritual life is diverse, different people may have different 
requirements for the living environment, so the object of environmental art design is not the same, to meet the different levels of different cultural requirements, so the environmental art design is an integrated discipline. In addition, the environment is a multi-faceted concept, relatively speaking, both from the micro-view, can also be analyzed from the macro aspects. Therefore, the environmental art design includes a lot of content, it can be urban planning, it can be small indoor planning. Environmental art design is the needs of people, science and technology support, integration of art as one of the overall planning. Environmental planning is now inseparable from environmental art design.

Peter Volcker points out that the fundamental nature of environmental art design is objective, visible, and environmental art is similar to architecture, sculpture, painting, and music, but its essence is different. Environmental art has a unique internal order, its purpose is to put the wisdom of mankind into nature. Refining the beauty of nature, to sublimation. When people face it, not the feeling of nature, but feel the power of design. Feel the greatness of human wisdom. In addition, it is necessary to make people aware of the value of environmental art, like a good job to retain talent, like a good environmental art design will allow real estate to get more space design.

\section{Artistic Design of Ecological Environment in China}

At present, China's ecological environment art design because of the late start of the reasons, so a large extent by the international impact of great. Some countries in the last century, the rapid development of ecological environmental art design, for example, the United States, Japan and other countries. Now, with the rapid development of developing countries like China, as well as the improvement of comprehensive national strength, aroused the wave of ecological environment art design. The original environmental planning for a time as a barrier to economic development, environmental change has become extremely urgent. However, it is this rapid expansion, leading to the current ecological environment of China's art design and development of deformity, "used to" popular, but also from another aspect of the Western culture to instill the arrogance of culture. Where is the West, is good, used to use this behavior is very common. China's rapid growth of this type, creating a blind imitation now, blindly use the situation. In the process of "taking", do not consider whether it is suitable, whether combined with our traditional culture, which is the development of ecological environment in China is very unfavorable. From the short behavior, the Western cultural products to get our country to use, a time can become a fashion, but not a long time, and this "use of" behavior of China's environmental art designer The creativity is a great deal of harm, making a large part of the innovative ideas with the designer lost enthusiasm, corrupting the environmental art design of our country a good atmosphere of innovation, the direct result of the consequences of the entire nation is the lack of environmental culture.

As part of China's environmental art design part of the designer quick success, regardless of local culture, mechanically applied Western ecological environment art results, resulting in ecological environment in China, the lack of local ecological culture is serious. Although the environmental art design is not static, but it is subject to historical tradition is inevitable, which no one can deny. China in the two thousand years under the influence of feudal culture, made a lot of outstanding cultural achievements at the same time, but also created the spirit of our people stereotypes. At present the legacy of the precious environmental art design localization culture can not be lost. With the acceleration of the process of globalization, China's many local characteristics of the building in the disappearance of local design elements in the weary, China is an ancient country, this happens happily. Moreover, many Western countries have now been vigilant about this, has introduced a variety of solutions, our country is still ignoring this point.

Over the years, China's economic development is very fast, people are very yearning for urban life, some rural and remote areas in order to develop the local economy at the expense of traditional ecological and environmental culture, and even many ancient culture have carried out some of the traditional ecological environment damage Behavior, many places to take the state to protect the ancient buildings and so on. These acts, although in a short period of time to win a lot of money, but in the long run, is tantamount to "kill chickens to take eggs." The local architectural community is 
generally not a single existence, but in a certain geographical conditions, along the historical context and human history to form a whole and exist. That is to say that the destruction of the local ecological environment art is actually equivalent to the destruction of the entire ecosystem. The preservation of the local architecture is not only the preservation of the building itself, but the preservation of the local eco-environment art design. Social development is a continuous development, not only in the material, but also reflected in the spirit of the above. In addition, some of the poor rural local buildings were destroyed, and China's current large number of migrant workers have a certain relationship, which shows that the lack of local culture and China's economic development is closely related to the status quo.

\section{Ecological Development of Environmental Art Design}

There is a philosopher in the West who has commented on the question of China. Many of the Chinese people have a history of thousands of years. If these things are used by the whole world, then the earth will be filled with more joy, if we despise oriental wisdom, then our own civilization can never reach the true sense of civilization. China is a country with a large population of 100 million, itself has so many good things for us, why do we like to advocate "use of doctrine" it, why not see their own glory know it is a misunderstanding. For the essence of the design of foreign ecological environment art, we should be properly absorbed, and can not simply "brought". Facing the ecological damage to give us the warning, do not panic, should be rational analysis of the problem, with the correct attitude towards foreign culture, because this grafted things may not be able to play a role in our soil, may bring us losses, Foreign does not mean advanced. Of course, for some good things we should learn from, at present, many of our large projects are designed by foreigners, our own good environmental art designers are scarce. So, we all hope to be born a good local designer. Rather than in the ecological environment art design in the copy of others model, which is more conducive to the sustainable development of China's environmental art design. We should be based on the actual situation in China, the use of the current high-tech, to create our own ecological environment art design works. Chinese designers should be in the correct absorption of foreign outstanding experience at the same time, continuous innovation, and constantly inherit their own fine traditions, to make a unique Chinese characteristics of the works.

As China's development in the past two years is very fast, so China has gradually become the focus of the world. Coupled with China's own huge market, so foreign investors in order to quickly open the Chinese market, at the use of cultural factors, dumping foreign culture to our country. To obliterate the local consciousness of our citizens. At present, the awareness of our citizens on the local community is very weak, almost can be said that there is no influence in many ways that foreign is good. So it is necessary to awaken the local consciousness of our citizens, which can effectively prevent the lack of localized ecological culture in the design of ecological environment art.

At present, under the economic globalization, China's ecological environment art and design office in a blind state, there have been some nondescript, blindly follow the trend of environmental art works, making the localization of environmental art elements serious. In this cultural diversity of space, to reflect the unique characteristics of our country, we need all the environmental art designers of the joint efforts. Eco-environmental art design as an important part of China's environmental art design is what we urgently need to improve. If a design work does not have local characteristics, then we can call it ecologically. Because the local ecological culture can reflect the local customs, an environmental art works if you do not take this into account, then can not be regarded as successful works.

At present, many parts of China are in the chaos of traditional buildings, many buildings are of great historical value. Eco-environmental art design should not abandon the tradition, for the building through the building should be re-construction and transformation of the attitude. For example, some of the retro buildings in Beijing, so that you can still feel the charm of ancient Chinese culture. In fact, the traditional building for the modern environmental art design reference is very large, we should not directly throw these things, demolition, but should carry out some 
recovery and recycling behavior. We can also put some of the essence of the part of the application of modern ecological environment in the design of which, through the addition of modern factors, to improve, sublimation, and to the moral and the title of the title, in the course of practice will carry forward the traditional architectural elements.

\section{Conclusion}

Ecological environment Art design is not a simple art, but in the pursuit of formal beauty at the same time compatible with local cultural customs and historical style, reflecting a cultural value, is a cultural form. At present, some of our ecological environmental art design works, there is such a problem, which is the environmental art design office in the initial stage can not be avoided, so we should correctly face these problems. The correct treatment of foreign culture to absorb the problem, strengthen the ecological environment art design localization concept, the traditional buildings to be re-built and transformed mentality, try to avoid the ecological environment art design "consumerism" too much manipulate. Improve the designer's own ability to analyze and solve problems, and create the ecological environment art works that fully consider the basic elements of foreign advanced factors in line with China's national conditions and make full use of China's traditional culture for thousands of years to do support. To achieve the human life behavior and ideological and psychological comprehensive understanding and respect for the purpose of creating a high quality of the living environment.

\section{References}

[1] Lu Fei, Wang Xiaoke. Greenhouse Gas Leakage and Net Emission Reduction Potential of Farmland Soil Carbon Fixation [J] .Acta Ecologica Sinica 2009 (09)

[2] Zhang Yuxin. Multi-scale analysis of plant species diversity of Quercus liaotungensis forest in Dongling Mountain, Beijing [J] .Acta Ecologica Sinica 2009 (05)

[3] JI Jiuchang. Classic Types and Ecological Adaptability of Riparian Forest Communities in the Upper Reaches of Wenyu River [J] .Acta Ecologica Sinica 2009 (03)

[4] Wei Xinliang.Study on Quantitative Evaluation of Rural Forest Ecological Suitability [J]. Journal of Zhejiang Forestry College 2009 (01)

[5] Chen Ke, Wang Xiaode. Changchun oil vine vine and other three kinds of dendritic plants drought resistance physiological indicators [J]. Journal of Zhejiang Forestry College. 2008 (03)

[6] Fu Bojie. International landscape ecology research new progress [J]. Acta Ecologica Sinica. $2008(02)$

[7] Li Tiansong. Creation of environmental art design of Chineseism [J]. Shanxi Architecture. 2007 (12) 